\title{
O strateških ciljih Instituta informacijskih znanosti
}

\author{
About strategic objectives of the Institute of Information Science
}

\section{Davor Šoštarič ${ }^{1}$}

IZVLEČEK: IZUM je jeseni leta 2019 pripravil srednjeročno strategijo za obdobje 2019-2024. Identificiranih je sedem strateških ciljev, ki so opisani po enotni metodologiji (analiza stanja, opis cilja, predvideni ukrepi za dosego cilja, pričakovani izidi in učinki, kazalci in kazalniki ter specifični dejavniki tveganja z ukrepi za obvladovanje). $V$ prispevku so opisani vsebina publikacije in načela, ki jih je IZUM upošteval pri njenem nastanku. Podrobneje so prikazani tudi strateški cilji.

KLJUČNE BESEDE: IZUM, strategija, COBISS, SICRIS, strateški cilji, odprtokodni sistemi, programska oprema, vzajemna katalogizacija, akademska digitalna zbirka, repozitorij, odprti dostop, HPC, visokozmogljivo računalništvo, superračunalnik, COBISS.net, SWOT, razvojne politike, obvladovanje tveganj, analiza stanja

ABSTRACT: In autumn 2019, IZUM prepared the medium-term strategy for 2019-2024. Seven strategic objectives are identified. They are described based on the common methodology (situation analysis, description of the objectives, planned measures to achieve the objectives, expected results and effects, indicators and specific risk factors with risk control measures). The content of the publication and the principles observed when writing are presented. Strategic objectives are described in detail.

KEYWORDS: IZUM, strategy, COBISS, SICRIS, strategic objectives, open source systems, software, shared cataloguing, Academic Digital Repository, repository, open access, HPC, high performance computing, supercomputer, COBISS.net, SWOT, development policies, risk management, situation analysis

\section{Uvod}

Velika večina IZUM-u podobnih javnih zavodov periodično objavlja strateške srednjeročne dokumente. IZUM je svoje kratkoročne cilje vedno zapisoval v rednih letnih delovnih načrtih, ki jih je po ustaljenih postopkih obravnaval in sprejemal njegov upravni odbor, dokončno pa potrjevalo matično ministrstvo, pristojno za raziskovalno dejavnost. Razumljivo je, da tako ni bilo mogoče kvalitetno spremljati posameznih projektov skozi večletno obdobje, še manj pa je bilo možno slediti soodvisnostim in aktualnim spremembam v življenjskih ciklih IZUM-ovih storitev.

V zadnjih letih se je IZUM srečal s kopico novih pričakovanj in zadolžitev, ki močno spreminjajo obzorja pred skoraj tremi desetletji začrtanih usmeritev. Pojavila se je potreba po jasnejši usmeritvi, ki ni utesnjena $v$ standardne operativne načrte, ampak je zasnovana na obsežnejši in širši perspektivi. Zato se je vodstvo IZUM-a odločilo, da izdela srednjeročno strategijo ter s tem pripravi dokument za opredelitev ključnih strateških ciljev, ki naj bi predstavljali stebre naše dejavnosti na čisto konkretnih področjih, za katera lahko že zdaj trdimo, da bodo zagotovo zaznamovala delovanje Instituta $v$ naslednjih letih.

\footnotetext{
${ }^{1}$ Davor Šoštarič, Institut informacijskih znanosti (IZUM), Maribor, Slovenija, davor.sostaric@izum.si.
} 
Rezultat te odločitve je dokument z naslovom Strateški načrt Instituta informacijskih znanosti (predvidena objava konec leta 2019).

\section{Priprava}

Direktor dr. Aleš Bošnjak je imenoval delovno skupino za pripravo dokumenta. Vanjo so bili vključeni posamezni avtorji, ki so napisali dele končnega besedila, lektorji, oblikovalec in člani direktorjevega kolegija. Za koordinatorja in pisca veznega besedila je bil postavljen Davor Šoštarič.

Kakšen teden je trajalo, da so bili identificirani osnovni strateški cilji - na koncu jih je bilo sedem. Zanje smo verjeli, da so ob upoštevanju sinergičnih učinkov, pravočasnem prepoznavanju pomena s strani vseh deležnikov ter aktivnem in odgovornem sodelovanju realno izvedljivi. Postavljeni so bili nosilci nalog, po elektronskih poteh pa so se razvile obsežne možganske nevihte. Želeli smo, da rezultat sledi evropskim vzorom podobnih dokumentov, in sicer tako po strukturi kot po vsebini. Hitro je bilo jasno, da z načinom kopiraj-in-prilepi iz obstoječih dokumentov, pretežno načrtov in poročil, na končni izdelek ne bomo mogli biti ponosni. Zato smo poleg vsebinskega nosilnega poglavja (že omenjenih sedem strateških ciljev) enako mero pozornosti posvetili spremljajočim delom besedila, ki skupaj z jedrom tvorijo nedeljivo celoto.

Pri pisanju besedila smo izhajali iz prepričanja, da je izhodišče za doseganje uravnoteženega razvoja treba iskati $v$ usklajevanju rešitev in dobrih praks, ki so nastale $v$ skoraj tridesetih letih obstoja IZUM-a, s pričakovanimi in identificiranimi potrebami IZUM-ove ciljne skupnosti skupaj s svetovnimi razvojnimi trendi na področju IZUM-ovega delovanja in poslanstva doma in po svetu. Zato smo se močno naslanjali na v preteklosti uspešno preizkušeno strateško upravljanje razvojnih procesov, ki so pripeljali do jasnih organizacijskih in informacijskih rešitev. Želeli smo prikazati jasno določene vizije, cilje, pasti, pogoje in tudi merila za spremljanje uspešnosti realizacije.

Osnutek je bil predstavljen kolektivu in članom upravnega odbora. Prejeli smo nekaj odličnih idej in sugestij in ob prehodu v poletje je bil dokument že pripravljen za zaključno redakcijo.

\section{Struktura}

Na začetku nas z besedilom Strateškemu načrtu na pot pozdravi direktor dr. Aleš Bošnjak.

Uvod ima tri podpoglavja. V podpoglavju Poslanstvo in vizija je nekaj osnovnih misli, med katerimi imajo posebno težo besede o sodelovanju, odprtosti, načelu »uporabe za javno dobro« ter o zavesti, da ima IZUM izvrstne, vedoželjne in sposobne strokovnjake. Sledi analiza SWOT, ki opiše tradicionalne štiri vidike (prednosti, slabosti, priložnosti in nevarnosti) z dvorazsežnostnega zornega kota (notranji in zunanji dejavniki). Uvodno poglavje sklenejo Vsebinski elementi. Na kratko so opisani povzetek obstoječega stanja, jedro s sedmimi strateškimi cilji, merila za realizacijo ter pristojnosti in odgovornosti predvidenih vključenih akterjev.

V nadaljevanju so dokaj podrobno opisane zakonodajne podlage, ki so temelj delovanja javnega zavoda IZUM. Razloženo je tudi, zakaj in kako je javni zavod IZUM opredeljen kot javni raziskovalni infrastrukturni zavod na eni in kot knjižnični informacijski servis v nacionalnem bibliografskem sistemu COBISS.SI na drugi strani. Opisani so upravljanje IZUM-a, delovanje 
dveh strokovnih svetovalnih teles, pravni in formalni odnosi s knjižnicami ter ponudniki drugih (pretežno tujih) podatkovnih baz oziroma informacijskih servisov. Sledijo povzetki prekrivanj oziroma stičnih točk z najpomembnejšimi slovenskimi in evropskimi razvojnimi politikami, strategijami, resolucijami in drugimi razvojnimi načrti.

Naslednji dve poglavji sta bistveni za razumevanje sedmih strateških ciljev. Najprej je $v$ Povzetku obstoječega stanja opisana vsebina delovanja IZUM-a, instrumenti za doseganje posameznih programskih ciljev pa so razvrščeni v nekaj sklopov. Na kratko so predstavljeni posamezni segmenti, programske rešitve, aplikacije, servisi, orodja ter pomen statusa regionalnega centra UNESCO, ki ga je pred osmimi leti dobil IZUM. V Izzivih kibernetske varnosti pa so omenjena načela, na podlagi katerih se IZUM spoprijema s perečo problematiko informacijske in kibernetske varnosti. Spoznamo ukrepe na fizični, omrežni, sistemski, aplikacijski in organizacijski ravni, pa tudi načrte v kratkoročnem obdobju.

Sledi ključni del besedila - že večkrat omenjenih sedem strateških ciljev. Ta del besedila opisujemo v naslednjem razdelku.

Splošni oziroma skupni dejavniki tveganja, ki so bolj ali manj neodvisni od posameznega strateškega cilja, so obdelani posebej v poglavju Dejavniki tveganja. IZUM vztraja, da mora biti zagotovljena njihova sistematična obravnava in omogočeno njihovo stopenjsko (o)vrednotenje na preverljiv in ponovljiv način. Te skupne dejavnike tveganja smo razdelili na časovno, finančno, kadrovsko, pravnoorganizacijsko, tehnološko, zakonodajno in poslovno komponento. Vsaka od njih je na kratko opisana, dodani so predvideni ukrepi.

V poglavju Merila za realizacijo strateških ciljev so povzeti agregirani, posamič omenjeni kazalci in kazalniki ter opisani generalni indikatorji, poglavje Proces realizacije strateških ciljev pa se osredotoča predvsem na pristojnosti in odgovornosti predvidenih vključenih akterjev. $\mathrm{Na}$ prvem mestu je seveda IZUM, omenjeni pa so tudi vsi drugi subjekti, od katerih pričakujemo odgovorno angažiranje: ministrstva, vlada, Javna agencija za raziskovalno dejavnost Republike Slovenije, univerze, raziskovalne organizacije, stanovska združenja in podobno.

Temu poglavju sledijo zaključne misli v obliki povzetka, seznam virov in napotki za vzporedno branje ter pojmovnik za lažje razumevanje strokovnih terminov in kratic.

\section{Sedem temeljnih izzivov}

Osrednje poglavje nosi naslov Strateški cilji in je razdeljeno na sedem podpoglavij, po eno za vsak cilj. Vsa so oblikovana na isti način. Udarno oblikovanemu nazivu cilja praviloma sledijo analiza stanja, opis cilja, predvideni ukrepi za dosego cilja, pričakovani izidi in učinki, kazalci in kazalniki ter specifični dejavniki tveganja z ukrepi za obvladovanje. Vsi strateški cilji so enakovredni; njihovo zaporedje ni povezano s prioritetami.

Prvi strateški cilj je nastal zaradi potrebe po razvoju nove generacije programske opreme. $\mathrm{V}$ letih od prvih programskih različic je tehnologija precej napredovala, spremenili so se tudi koncepti in arhitektura programskih rešitev. Kot bistveno novost poudarjamo implementacijo spletnih aplikacij, ki delujejo v običajnih brskalnikih. 
Nenehne spremembe informacijsko-komunikacijskih tehnologij so primarni razlog za drugi strateški cilj. Licenčne odvisnosti od lastnikov in nosilcev pravic postajajo nevzdržno breme in opravljene analize kažejo, da je zdaj pravi trenutek za prehod na odprtokodne sisteme.

Naloge IZUM-a med drugim zajemajo koordinacijo razvoja in delovanja vzajemnega bibliografskega sistema. Osnova za delovanje knjižničnega informacijskega sistema so bibliografski zapisi. Njihova kakovost in popolnost sta pomembni za pravilno delovanje knjižničnih aplikacij, kar pogojuje uvrstitev tretjega strateškega cilja.

Naslednji strateški cilj naslavlja nekaj, česar v Sloveniji še nimamo (razen morda posameznih individualnih in izoliranih rešitev). Želimo imeti sistem, ki bo omogočal iskanje in dostop do vseh virov, ki jih knjižnice ponujajo svojim uporabnikom.

Odprti dostop do recenziranih znanstvenih informacij je zelo razširjena zahteva predvsem evropskih raziskovalnih okolij v zadnjih nekaj letih. Kljub sprejeti slovenski nacionalni strategiji in akcijskemu načrtu Slovenija na področju odprtega dostopa zamuja. IZUM lahko s svojim znanjem in zavidanja vrednimi rezultati aktivno pomaga, zato je umestitev tovrstne problematike med IZUM-ove strateške cilje normalna posledica.

Z naslednjim strateškim ciljem IZUM vstopa na področje zahtevnih računskih obdelav, saj bo slovenskim raziskovalcem zagotavljal uporabo najsodobnejše superračunalniške tehnologije.

Sedmi strateški cilj je usmerjen $v$ geopolitični prostor Jugovzhodne Evrope. Vključevanje $v$ COBISS. net $v$ luči razvojne naravnanosti Evropske unije lahko prispeva k homogenizaciji in harmonizaciji bibliografskih sistemov ne glede na zelo različen status držav na ciljnem geografskem področju glede pridruženosti ali pridruževanja Evropski uniji. Uporabniškim skupnostim $v$ ciljnih državah želimo pomagati, da se približajo ravni, ki je na voljo vsem deležnikom v Sloveniji.

\subsection{Nova generacija programske opreme COBISS}

Programska oprema COBISS3 ima že častitljivo zgodovino. Zaradi nenehnih potreb po prilagajanju spremenjenim konceptom, večjezičnosti, arhitekturni zastarelosti, obremenjenosti $s$ kompatibilnostjo $s$ starejšimi verzijami in prilagodljivosti posameznim knjižnicam je po nepotrebnem postala kompleksna in zahtevna za vzdrževanje. Konec leta 2018 je bila sprejeta strateška odločitev, da se celotna produkcija za končne uporabnike prenese $z$ dosedanjih platform $v$ odprtokodna okolja.

Nova generacija programske opreme COBISS ne bo več zahtevala dodatnih namestitev posebne programske opreme na lokalnih terminalnih napravah (odjemalci), kar je danes precejšnja ovira zaradi neizmerne heterogenosti dostopne strojne opreme. Namesto tega bodo vse aplikacije spletne in bodo delovale $v$ običajnih brskalnikih, dodatni posegi ne bodo potrebni.

Pričakujemo izboljšano uporabniško izkušnjo, popolno podporo za nove standardizirane nabore znakov, skalabilnost, robustnost in odzivnost, odprte vmesnike za integracijo z drugimi sistemi ter seveda lažje vzdrževanje $z$ avtomatiziranimi namestitvami in nadgradnjami.

Med ukrepi za dosego ciljev so zapisane prilagoditve programske arhitekture, izdelava lastnega ogrodja za generiranje uporabniških vmesnikov, dodatno intenzivno izobraževanje za sodelavce $v$ skupinah za razvoj programske opreme in za sistemsko podporo, spoznavanje 
novih konceptov (operacijski sistem, baza podatkov ...) ter razvoj avtomatiziranih postopkov in mikroservisov. Posebna pozornost je namenjena migraciji podatkov iz starega sistema $v$ novi.

\subsection{Usmeritev v odprtokodne rešitve}

IZUM je bil že večkrat prisiljen $v$ menjave tehnologij, tako za sistemsko kot za aplikativno infrastrukturo. Izvirna programska oprema COBISS je bila razvita na operacijskem sistemu OpenVMS, njena naslednica pa je temeljila na operacijskem sistemu Windows $\mathrm{s}$ komercialnima produktoma za podatkovno bazo. To je bila dobra poslovna odločitev, saj smo bili upravičeni do zelo ugodnih akademskih popustov. Ker pa se je $v$ zadnjih letih ta licenčna politika drastično spremenila, smo začeli iskati alternativne poti za prenos aplikacijskih strežnikov in strežnikov za baze podatkov na odprtokodne operacijske sisteme.

Nova okolja za prehod na odprtokodno podprte rešitve so že definirana: operacijski sistem CentOS (Linux), relacijska baza PostgreSQL, virtualizacijska platforma KVM/Proxmos in sistemska podpora za odprtokodne projekte, kot so SOLR, Elasticsearch, Apache ... Med prvimi nalogami je tako najprej izpeljava ustreznih postopkov za nabavo vseh potrebnih sistemov, vzporedno pa že potekajo ustrezna izobraževanja. Hkrati se intenzivno dela na natančnem načrtovanju migracij obstoječih storitev in podatkov na novo raven, tako da bo prehod čim manj boleč.

Med kazalci in kazalniki najdemo neposredno merljive ekonomske učinke, saj pričakujemo, da bo razmerje med trenutnimi stroški za plačilo licenc današnjih strežniških produktov (predvsem Microsoft in Oracle) in stroški vzdrževanja novih produktov (ki niso brezplačni!) zelo ugodno.

\subsection{Normalizacija, standardizacija in globalizacija katalogizacijskih procesov}

Osnova za delovanje knjižničnega informacijskega sistema so bibliografski zapisi. Njihova kakovost in popolnost sta pomembni za pravilno delovanje knjižničnih aplikacij. Podatki iz sistema COBISS se uporabljajo tudi za druge namene, in ne zgolj za osnovne funkcije knjižničnega kataloga.

Vzajemna katalogizacija omogoča racionalno delitev dela in prihranek pri postopku obdelave knjižničnega gradiva in vodenju katalogov, temelji pa na načelu medsebojne izmenjave zapisov. Pogoj za to so standardizirana pravila za obdelavo gradiva. Aktualna je tudi mednarodna izmenjava podatkov, kjer se je treba zavedati razlik med domačo in tujo katalogizacijsko prakso. Za mednarodno izmenjavo je bistveno, da so zapisi dovolj strukturirani in se lahko, čeprav se $v$ različnih državah uporabljajo različni formati in pravila, definirajo preslikave med zapisi.

V želji po zagotovitvi čim kvalitetnejših zapisov vztrajamo pri tem, da so katalogizatorji vrhunsko usposobljeni, kar predvsem pomeni poglobljeno izobraževanje in osvežitvene delavnice za katalogizatorje ter sprotna preverjanja izdelanih zapisov. $\mathrm{V}$ pomoč katalogizacijskim procesom izpostavljamo tri ukrepe: spremljanje mednarodnih in vzdrževanje domačih standardov, zagon Splošnega geslovnika COBISS, ki bo pokril vsa področja znanja, in dopolnjevanje programske opreme s funkcionalnostmi za izboljšanje kakovosti zapisov. 


\subsection{Nacionalna akademska digitalna zbirka}

Nacionalno akademsko digitalno zbirko vidimo kot relevantni nacionalni vir podatkov za raziskovalce in študente. Slovenija namreč še vedno nima enotnega iskalnega sistema za iskanje in dostop do celotnih besedil elektronskih informacijskih virov. IZUM že leta raziskuje, testira in analizira možne rešitve, ki naj bi zadovoljile najširši krog uporabnikov slovenskega raziskovalnega prostora. Na podlagi tega je bil pripravljen idejni osnutek enotne platforme. Analizirane so možnosti integracije nekaterih svetovnih ponudnikov orodja za odkrivanje podatkov (angl. discovery tool) v COBISS+. Osnutek je bil predstavljen skupini vidnih slovenskih strokovnjakov s tega področja.

IZUM vztraja pri stališču, da mora iskalnik COBISS+ omogočati iskanje in dostop do vseh virov, ki jih knjižnica ponuja svojim uporabnikom, vključno s celotnimi besedili naročenih elektronskih informacijskih virov.

Vključitev orodja za enotno preiskovanje za vsa okolja zahteva poznavanje tehnologij indeksiranja, integracij API, povezovanj OpenURL ter avtentikacijskih in avtorizacijskih infrastrukturnih rešitev. Ob izvedbi javnega razpisa za nakup orodja za vključitev v COBISS+ prek vmesnikov API ima prvo prioriteto razvoj ciljnih portalov za posamezna okolja, sočasno pa se bodo izvajale aktivnosti za zagotovitev organizacijske in tehnološke strukture za kvalitetno podporo uporabnikom.

Ko bo ta strateški cilj dosežen, pričakujemo poenoteno uporabniško izkušnjo, preglednejšo in enostavnejšo dostopnost elektronskega gradiva ter racionalizacijo obstoječih procesov za preiskovanje virov.

\subsection{Podpora odprtemu dostopu}

V Sloveniji trenutno obstaja osem različnih lokalnih repozitorijev, ki pa med seboj niso sinhronizirani. Vanje se na različne načine vnašajo zapisi za gradivo in tudi celotna besedila. Zapisi niso v celoti povezani s sistemom COBISS, ki bi zanje edini lahko zagotavljal ustrezne metapodatke. To želimo preseči. Zato je treba natančno določiti, kateri podatki se bodo zbirali in obdelovali, kje bodo shranjeni, kdo jih bo priskrbel in kdo bo zanje odgovoren.

$\checkmark$ implementaciji bo treba obstoječe distribuirane in heterogene repozitorije združiti pod okrilje enotnega nacionalnega repozitorija odprte znanosti, ki bo služil kot referenčni in bo tesno povezan $\mathrm{S}$ sistemom COBISS. $\mathrm{S}$ tem bo vzpostavljen pravi referenčni nacionalni repozitorij odprte znanosti, $v$ katerem se bo vsak zapis pojavil le enkrat in bo na voljo $v$ vseh lokalnih okoljih. Vse objavljene publikacije, ki so posredno ali neposredno financirane $z$ javnimi sredstvi, bodo shranjene $v$ enotnem sistemu in dostopne javnosti, saj bo zagotovljen tudi odprti dostop do celotnih besedil. Pričakujemo, da bo Slovenija postala aktivna članica evropskih sistemov za odprti dostop, zato je predvidena povezava med sistemoma COBISS.SI in OpenAire.

\subsection{IZUM kot superračunalniški in nacionalni podatkovni center}

IZUM se pridružuje središčem za zahtevne računske obdelave. Slovenskim raziskovalcem bo zagotavljal uporabo najsodobnejše visokozmogljive računalniške tehnologije. $S$ tem bo znanstveni sferi ponujal prosti dostop do bistveno povečanih zmogljivosti znanstvenega računanja in analize masovnih podatkov ter tudi hranjenja večjih količin digitalnih podatkov. 
Uporabnikom bo s tem omogočen preprost, standardiziran dostop do razpršene infrastrukture za paralelno računanje in obdelavo podatkov.

Med kritičnimi dejavniki izpostavljamo zagotovitev stabilnega financiranja za tekoče stroške in strokovni kader, pomisliti pa je treba tudi na pravočasno zamenjavo iztrošenih komponent zahtevne opreme tako že v času trajanja projekta kot tudi po njegovem zaključku.

Prepričani smo, da bo superračunalnik prispeval k povečanju obsega in kvalitete razvojnoraziskovalnih projektov, ki za svojo realizacijo potrebujejo povečane računske zmogljivosti, pri tem pa bo tudi bistveno pripomogel k širšemu razvoju kadrov s področja visokozmogljivega računalništva, saj bo zagotavljal široko dostopnost za namene izobraževanja in usposabljanja.

\section{7 Širitev in prenos znanja v okviru mreže COBISS.net}

COBISS.net je sodobno zasnovana informacijska mreža medsebojno povezanih knjižničnih informacijskih sistemov COBISS.xx in E-CRIS.xx, oblikovana po slovenskem vzoru. V državah Jugovzhodne Evrope deluje kot infrastruktura za izmenjavo informacij o intelektualni produkciji, s tem pa tudi kot spodbujevalec medkulturnega dialoga $v$ regiji. Poleg Slovenije sodelujejo še naslednje države: Albanija, Bolgarija, Bosna in Hercegovina (znotraj katere deluje kot samostojna entiteta še Republika Srbska), Črna gora, Kosovo, Severna Makedonija in Srbija.

Pričakujemo, da se bo v mreži z njenim razvojem pokazalo še več podobnih sinergij tudi na področju tesnejšega povezovanja sistemov o raziskovalni dejavnosti (npr. v okviru prenosa podatkov o projektih, kjer bi bili znotraj istega projekta udeleženi raziskovalci iz različnih držav mreže). V mrežo COBISS. net želimo povezati vse visokošolske in raziskovalne organizacije ter visokošolske, specialne in splošne knjižnice v ciljnih državah, hkrati pa vzpostaviti kompatibilne sisteme za evalvacijo raziskovalne dejavnosti. $S$ tem se bo zaostanek razvojnih možnosti lokalnega okolja $v$ teh državah bistveno zmanjšal v primerjavi z dosežki Slovenije in se močno približal ravni, ki je na voljo vsem deležnikom v Sloveniji.

\section{Merila za realizacijo, pristojnosti in odgovornosti}

Največja nagrada za uspešno realizacijo opisanih strateških ciljev bo končno zadovoljstvo uporabnikov IZUM-ovih storitev. Tega ne moremo neposredno numerično meriti, saj gre za zelo kompleksno dejavnost, ki jo je težko zajeti v preproste fizične kazalce. COBISS in SICRIS uporabljajo vsi raziskovalci, vsi udeleženci izobraževanja, vsi strokovni delavci, avtorji, ustvarjalci in obiskovalci knjižnic.

Zavestno smo se odločili, da posebnih mejnikov ne definiramo, so pa pri posameznih izpostavljenih strateških ciljih našteti kazalniki, na osnovi katerih bomo spremljali uspešnost njihove realizacije. Na tej podlagi in podkrepljeno z izsledki poglobljenih analiz posameznih rezultatov bomo morebiti dokument sčasoma tudi dopolnili ali spremenili.

IZUM ni sam sebi namen. Vidimo ga kot zelo pomemben instrument pri intenziviranju izgradnje informacijske in digitalne družbe oziroma sodobne družbe znanja. Ključna značilnost bi morala biti sinergija. V IZUM-u kategorično zavračamo kakršne koli ideje o prevalitvi posameznih odgovornosti na tretje subjekte in vztrajamo pri delitvi pristojnosti in odgovornosti med več deležnikov; nekaj jih je tudi izrecno navedenih. 


\section{Zaključek}

Večina podobnih dokumentov postavlja svojo strategijo $v$ središče razvojnega in življenjskega kroga. IZUM ima drugačen pogled. $V$ središču niso leporečni dokumenti, ampak življenjska realnost. IZUM-ova dejavnost ima podlago $v$ natanko definiranih okvirih. Zato so $v$ ospredje postavljeni produkcijska skrb ter vzdrževanje in upravljanje ključnih informacijskih sistemov. Dva temeljna podporna stebra pri tem sta standardni razvoj (novosti, nove funkcionalnosti, zahteve skupnosti in podobno) na eni in novi izzivi s prihajajočimi priložnostmi in vizijami na drugi strani. Na tako oblikovano življenjsko spiralo sovplivajo številni notranji in zunanji dejavniki, kot so strokovni in laični uporabniki, utrip uporabniške skupnosti, zgledovanje po podobnih uspešnih sistemih, globalni razvojni in tehnološki trendi in podobno. Strateški načrti (popularno imenovani tudi strategije, razvojne politike, bele knjige itd.) so tako samo eden od instrumentov, ki so na voljo. Pomemben je končni učinek. Pri tem se moramo zavedati, da ta življenjski krog (spirala) predstavlja nikoli zaključeno zgodbo.

Opisani strateški cilji se sicer nanašajo na petletno obdobje, kar pa nikakor ne pomeni neprebojnega oklepa, ki ne dopušča morebitnih kasnejših posegov. Po potrebi in na podlagi analiz ter sprotnega spremljanja poteka dogodkov in vmesnih faz realizacije strateških ciljev bo dokument odprt za dopolnitve in spremembe, morda pa tudi za opustitev posameznih ukrepov.

\section{Reference}

Strateški načrt Instituta informacijskih znanosti, (v tisku) 2019. Maribor: Institut informacijskih znanosti. 